\title{
IMPLEMETASI YURIDIS TERHADAP KEDUDUKAN WAKAF PRODUKTIF BERBASIS PENINGKATAN EKONOMI MASYARAKAT DI INDONESIA
}

\author{
Naimah \\ Dosen Fakultas Ekonomi dan Bisnis Islam UIN Antasari Banjarmasin
}

\begin{abstract}
Productive waqf is the property that is represented for use in productive activities and, the profits are distributed in accordance with the purpose of waqf. Such as land waqf for planting use, springs for water, and others. The basis for determining the legal status of productive waqf is Law No. 41 of 2004. Chapter V of Law 41 of 2004 is an expansion of the previous Wakaf Law which regulates the management of waqf property, in which the obligations of Nazir are arranged in accordance with the principles of sharia, and in article 43 verse 2 it is explained that the management and development of waqf property are done productively. Law No. 41 of 2004 about W akaf is also a momentum of waqf empowerment because it contains a comprehensive understanding and management pattern of potential empowerment of waqf in a modern way. The birth of the Law of the Republic of Indonesia No. 41 of 2004 on Wakaf directed to empower waqf which is one of the instruments in building the socio-economic life of Muslims. Productive waqf is basically an implementation for reaching the goal to improve the welfare/prosperity of the community through the models of productive economic enterprises so that the benefits of waqf property can be obtained efficiently and sustainable. To materialize productive waqf, there are at least four principles that need to be taken into account, which are the principle of eternal benefits, the principle of accountability, the principle of management professionalism, and the principle of social justice.
\end{abstract}

\begin{abstract}
Abstrak: Wakaf produktif adalah harta benda atau pokok tetap yang diwakafkan untuk dipergunakan dalam kegiatan produksi dan hasilnya di salurkan sesuai dengan tujuan wakaf. Seperti wakaf tanah untuk digunakan bercocok tanam, mata air untuk diambil airnya dan lain- lain. Dasar penetapan terhadap status hukum wakaf produktif.dalam Undang-undang Nomor 41 Tahun 2004 adalah ijtihad. Bab V UndangUndang 41 Tahun 2004 merupakan pengembangan dari Undang-undang wakaf sebelumnya yang mengatur tentang pengelolaan harta wakaf, dimana kewajiban nazir diatur secara gamblang sesuai dengan prinsip syariah dan pada pasal 43 ayat 2 dijelaskan bahwa pengelolaan dan pengembangan harta benda wakaf dilakukan secara produktif. Undang-undang Nomor 41 Tahun 2004 Tentang Wakaf ini juga menjadi momentum pemberdayaan wakaf secara produktif sebab di dalamnya terkandung pemahaman yang komprehensif dan pola manajemen pemberdayaan potensi wakaf secara modern. Lahirnya UndangUndang Republik Indonesia No. 41 tahun 2004 tentang Wakaf diarahkan untuk memberdayakan wakaf yang merupakan salah satu instrumen dalam membangun kehidupan sosial ekonomi umat Islam. Wakaf produktif pada dasarnya merupakan implementasi tujuan wakaf yaitu kemaslahatan/ kesejahteraan masyarakat melalui model-model usaha ekonomi yang produktif, sehingga manfaat dari harta wakaf dapat berdaya guna secara optimal dan berkesinambungan. Untuk merealisasikan wakaf produktif maka paling tidak harus mempertimbangkan empat azas, yaitu asas keabadian manfaat, asas pertanggung-jawaban, asas profesionalitas managemen, dan asas keadilan sosial.
\end{abstract}

Kata Kunci: Wakaf Produktif; Ekonomi Masyarakat

\section{Pendahaluan}

Sebagai agama rahmatanlilalamin, Islam senantiasa menghendaki tatanan kehidupan ekonomi umatt berdiri kokoh dalam konstruksi nilai-nilai keadilan. Islam senantiasa berusaha meningkatkan ekonomi bagi seluruh umat manusia dengan berpedoman pada alquran dan sunnah. Konsistensi Islam memperhatikan para fakir dan miskin dan berusaha mengangkat derajat mereka pada kedudukan yang lebih tinggi dalam aspek ekonomi, dan ini salah satu tujuan dari syariat Islam.

Di dalam ajaran Islam, ada dua tata hubungan yang harus dipelihara oleh para pemeluknya. Keduanya disebut dengan dua kalimat bablum minallab wa bablum minan nas. Hubungan itu

dilambangkan dengan tali, karena ia menunjukkan ikatan atau hubungan antara manusia dengan Tuhan dan antara manusia dengan manusia. Kedua hubungan ini harus harus berjalan secara serentak dan bersama-sama ${ }^{1}$.

Jika kita menggali syariat Islam, akan ditemukan bahwa tujuan syariat Islam adalah demi kemaslahatan manusia. Allah memberi manusia kemampuan dan karakter yang beraneka ragam. Dari sinilah, kemudian timbul kondisi dan lingkungan yang berbeda di antara masing-masing individu. Ada yang miskin, kaya, cerdas, bodoh,

\footnotetext{
${ }^{1}$ Mohammad Daud Ali, Sistem Ekonomi Islam: Zakat dan Wakaf (Penerbit Universitas Indonesia, 1988), 29.
} 
kuat dan lemah, di balik semua itu tersimpan hikmah, di mana Allah memberi kesempatan kepada yang kaya menyantuni yang miskin, yang cerdas membimbing yang bodoh dan yang kuat menolong yang lemah. Yang demikian, merupakan wahana bagi manusia untuk melakukan kebajikan sebagai upaya mendekatkan diri kepada Allah, sehingga interaksi antarmanusia terus terjalin ${ }^{2}$.

Firman Allah SWT dalam surat adzDzaariyaat ayat 19:

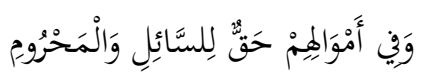

Artinya : "dan pada harta-harta mereka ada hak untuke. orang miskin yang meminta dan orang miskin yang tidak mendapat bagian."

Kepemilikan harta benda yang tidak menyertakan kepada kemanfaatan terhadap orang lain merupakan sikap yang tidak disukai oleh Allah SWT. Agama Islam selalu menganjurkan agar selalu memelihara keseimbangan sebagai makhluk pribadi dan makhluk sosial dalam tata kehidupan masyarakat. Dalam konsep Islam, dikenal istilah jariyah artinya mengalir. Maksudnya, sedekah atau wakaf yang dikeluarkan, sepanjang benda wakaf itu dimanfaatkan untuk kepentingan kebaikan maka selama itu pula si wakif mendapat pahala secara terus-menerus meskipun telah meninggal dunia ${ }^{3}$, 4-6:

Firman Allah SWT dalam surat Al-Tiin ayat

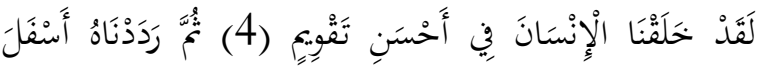

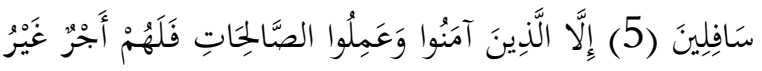

Artinya: "Sesunggubnya Kami telah menciptakan manusia dalam bentuk yang sebaik-baiknya. kemudian Kami kembalikan Dia ke tempat yang serendah-rendabnya (neraka), kecuali orang-orang yang beriman dan mengerjakan amal saleb; Maka bagi mereka pahala yang tiada putus-putusnya."

Penegakan keadilan sosial dalam Islam merupakan kemurnian dan realitas ajaran agama. Orang yang menolak keadilan social ini dianggap sebagai pendusta agama (Q.S al-Ma'un:17). Subtansi yang terkandung dalam ajaran wakaf sangat tampak adanya semangat menegakkan

\footnotetext{
${ }^{2}$ Muhammad Abid Abdullah Al-Kabisi, Hukum Wakaf: Kajian Kontemporer Pertama dan Terlengkap tentang Fungsi dan Pengelolaan Wakaf serta Penyelesaian atas Sengketa Wakaf (Jakarta: IIMaN Press \& Dompet Dhuafa Republika, 2004), 83.

3 Ahmad Rofiq, Hukum Islam di Indonesia (RajaGrafindo Persada, 1997), 492.
}

keadilan sosial melalui pendermaan harta untuk kebajikan umum. Walaupun wakaf sebatas amal kebajikan yang bersifat anjuran, tetapi daya dorong untuk menciptakan pemerataan kesejahteraan sangat tinggi . ${ }^{4}$

Sebagai agama rahmatanlilalamin, Islam senantiasa menghendaki tatanan kehidupan ekonomi umatt berdiri kokoh dalam konstruksi nilai-nilai keadilan. Islam senantiasa berusaha meningkatkan ekonomi bagi seluruh umat manusia dengan berpedoman pada alquran dan sunnah. Konsistensi Islam memperhatikan para fakir dan miskin dan berusaha mengangkat derajat mereka pada kedudukan yang lebih tinggi dalam aspek ekonomi,syariah. Sejarah pengaturan ekonomi syariah, khususnya hukum wakaf dapat dilihat melalui terbitnya Undang-Undang 41 tahun 2004 tentang wakaf,

Wakaf sebagai shadaqah jariyah dapat memberikan implikasi besar bagi peningkatan ekonomi umat, wakaf juga dikategorikan sebagai ibadah sosial yang berinteraksi membangun hubungan harmonis antara sesama manusia dan manusia dengan Allah. Saat wakif mendistribusikan kekayaan terjadi hubungan sosial (hablumminannas) dalam usaha meningkatkan kesejahteraan umat, sedangkan keikhlasan wakif saat mendistribusikan wakaf di jalan Allah terjadi hubungan ketakwaan (Hablumminallab) sebagai refleksi rasa syukur terhadap nikmat Allah. Kedua hubungan di atas mengandung nilai sosial ekonomi religius yang dapat membawa perubahan besar dalam tatanan kehidupan umat dengan menekankan rasa tanggungjawab sosial bagi peningkatan kesejahteraan diantara umat Islam, sebab Nabi Muhammad SAW telah memberikan peringatan kepada umat Islam dengan mengatakan, "Tidak beriman orang yang tidur kenyang, sementara tetangganya kelaparan."

Dengan menunaikan ibadah wakaf akan memberi pengaruh terhadap kehidupan social yang positif dan dinamis penuh rasa tanggung jawab social, terhindar dari pengaruh paham negative. Karenannya prinsip dasar wakaf bertujuan untuk menciptakan keadilan social merupakan implementasi dari sistim ekonomi yang mendorong dan mengaku hak milik individu dan masyarakat secara seimbang ${ }^{5}$.

4 Direktorat Pemberdayaan Wakaf dan Direktorat Jenderal Bimbingan Masyarakat Islam, Paradigma Baru Wakaf di Indonesia (Jakarta: Direktorat Pemberdayaan Wakaf, 2008), 85.

${ }^{5}$ Wakaf dan Islam, 90. 
Salah satu institusi atau pranata social Islam yang mempunyai nilai social ekonomi adalah lembaga perwakafan. Sebagai kelanjutan dari ajaran tauhid, yang berarti bahwa segala sesuatu berpuncak pada kesadaran akan adanya Allah SWT. lembaga perwakafan adalah salah satu perwujudan keadilan social dalam Islam. Prinsip pemilikan harta dalam Islam tidak dibenarkan dikuasai oleh sekelompok orang ${ }^{6}$.

Di tengah problem sosial umat dan tuntutan akan kesejahteraan ekonomi akhir-akhir ini, keberadaan wakaf manjadi sangat strategis. Disamping sebagai salah satu aspek ajaran Islam yang berdimensi spiritual, wakaf juga merupakan ajaran yang menekankan pentingnya peningkatan ekonomi. Wakaf dalam sejarah telah berperan penting dalam membantu meningkatkan ekonomi umat.

Wakaf telah disyariatkan dan dipraktekkan oleh umat Islam seluruh dunia sejak zaman Rasulullah sampai sekarang. Hukum wakaf merupakan cabang yang terpenting dalam syariat Islam sebab ia terjalin ke dalam seluruh kehidupan ibadah dan perekonomian social kaum muslimin ${ }^{7}$.

Firman Allah SWT Dalam Surat QS. AliImran ayat 92:

لَْْ تَنالوا البر حتى تنفقوا مما تحبون وما تنفقوا من شئ فإن الله

Artinya: "Kamu sekali-kali tidak sampai kepada kebajikan (yang sempurna), sebelum kamu menafkabkan sebahagian harta yang kamu cintai. Dan apa saja yang kamu nafkabkan, maka sesunggubnya Allah mengetabuinya".

Hal ini sesuai dengan fungsi wakaf yang disebutkan pasal 5 Undang-Undang Nomor 41 tahun 2004 Tentang Wakaf yang menyatakan bahwa wakaf berfungsi mewujudkan potensi dan manfaat ekonomis harta benda wakaf untuk kepentingan ibadah dan untuk memajukan kesejahteraan umum.

Bagi umat Islam Indonesia, wacana wakaf tunai produktif memang masih relative baru. Bisa dilihat dari peraturan yang melandasinya. Majelis Ulama Indonesia (MUI) baru memfatwakannya pertengahan Mei 2002. Selama ini, wakaf yang populer di kalangan umat Islam Indonesia terbatas tanah dan bangunan yang diperuntukkan tempat ibadah, rumah sakit dan pendidikan.

\footnotetext{
${ }^{6}$ Siah Khosyi'ah, Wakaf dan Hibah: Perspektif Ulama Fiqh dan Perkembangannya di Indonesia (Penerbit CV. Pustaka Setia, 2010), 5.

${ }^{7}$ Khosyi'ah, 87.
}

Di masa pertumbuhan ekonomi di Indonesia yang cukup memprihatinkan saat ini, sesungguhnya peranan wakaf di samping instrumen-instrumen ekonomi Islam lainnya seperti zakat, infaq, sedekah dan lain-lain belum dapat dirasakan manfaatnya untuk meningkatkan taraf hidup masyarakat khususnya di bidang ekonomi. Peruntukan wakaf di Indonesia yang kurang mengarah pada pemberdayaan ekonomi umat dan cenderung hanya untuk kepentingan ibadah khusus dapat dimaklumi, karena memang pada umumnya ada keterbatasan umat Islam tentang pemahaman wakaf, baik mengenai harta yang diwakafkan maupun peruntukannya.

Wakaf bisa dijadikan sebagai lembaga ekonomi yang potensial untuk dikembangkan selama bisa dikelola secara optimal, karena institusi perwakafan merupakan salah satu aset kebudayaan nasional dari aspek sosial yang perlu mendapat perhatian sebagai penopang hidup dan harga diri bangsa. Oleh karena itu, kondisi wakaf di Indonesia perlu mendapat perhatian ekstra.

Dilihat dari segi peruntukannya, wakaf dibagi menjadi dua yaitu konsumtif dan produktif. Wakaf konsumtif yaitu harta benda atau pokok tetapnya wakaf dipergunakan langsung untuk kepentingan umat. Pada umumnya wakaf di Indonesia digunakan untuk pembangunan masjid, mushalla, sekolahan, rumah yatim piatu, makam.

Selama ini pemanfataan wakaf dilihat dari segi sosial, khususnya untuk kepentingan peribadatan memang cukup efektif. Akan tetapi dampaknya kurang berpengaruh positif dalam kehidupan ekonomi masyarakat apabila peruntukan wakaf hanya terbatas pada hal-hal di atas. Tanpa diimbangi dengan wakaf yang dikelola secara produktif, maka kesejahteraan ekonomi masyarakat yang diharapkan dari lembaga wakaf tidak akan dapat terealisasi secara optimal.

Wakaf produktif dapat didefinisikan sebagai harta yang digunakan untuk kepentingan produksi baik dibidang pertanian, Perindustrian, perdagangan dan jasa yang manfaatnya bukan pada benda wakaf secara langsung, tetapi dari keuntungan bersih dari hasil pengembangan wakaf yang diberikan kepada orang-orang yang berhak sesuai dangan tujuan wakaf.

Setelah Indonesia merdeka, pembenahan terus dilakukan terhadap hukum perwakafan di Indonesia. Tahun 1953, Departemen Agama membuat petunjuk mengenai pelaksanaan wakaf yang disempurnakan pada tahun 1956 tentang prosedur perwakafan. Perwakafan makin mendapat tempat dalam peraturan perundangan dengan adanya Undang-Undang Pokok Agraria Nomor 5 tahun 1960. Pasal 49. Undang-Undang 
ini menyatakan bahwa perwakafan tanah milik diatur oleh Peraturan Pemerintah tujuh belas tahun berikutnya, Peraturan Pemerintah yang dimaksud yaitu Peraturan Pemerintah Nomor 28 tahun 1977. Peraturan Pemerintah ini kemudian diikuti dengan seperangkat peraturan pelaksanaannya oleh Departemen Agama dan Departemen Dalam Negeri dan beberapa instruksi Gubernur.

Wakaf telah mengakar dalam kehidupan masyarakat Islam, dan menjadi penunjang utama perkembangan kehidupan masyarakat. Hal ini bisa dilihat pada kenyataan bahwa hampir semua rumah ibadah, perguruan Islam dan lembagalembaga keagamaan Islam dibangun diatas tanah wakaf. Dan satu kemajuan yang sangat signifikan bagi umat Islam, ketika dikeluarkannya UndangUndang Perwakafan yaitu Undang-Undang Nomor 41 tahun 2004 Tentang Wakaf.

Setelah di resmikannya Undang-Undang Nomor 41 tahun 2004 Tentang Wakaf, kemudian diteruskan dengan dibentuknya Badan Wakaf Indonesia ( BWI ) sebagai lembaga independen yang secara kusus mengelola dana wakaf dan beroperasi secara nasional. Tugas dari lembaga ini adalah untuk memajukan dan mengembangkan perwakafan nasional di Indonesia. BWI ini berkedudukan di ibukota negara dan dapat membentuk perwakilan di provinsi atau kabupaten atau kota sesuai dengan kebutuhan ${ }^{8}$.

\section{Konsep Tentang Wakaf Produktif}

Wakaf adalah suatu pranata yang berasal dari Hukum Islam. Oleh karena itu, apabila membicarakan masalah perwakafan pada umumnya dan perwakafan tanah pada khususnya, tidak mungkin untuk melepaskan diri dari pembicaraan tentang konsepsi wakaf menurut Hukum Islam. Akan tetapi, dalam Hukum Islam tidak ada konsep yang tunggal tentang wakaf ini, karena terdapat banyak pendapat yang sangat beragam ${ }^{9}$.

Ditinjai dari segi bahasa wakaf berasal dari bahasa Arab waqf yang berasal dari kata woqofayaqifu-waqfa yang berarti ragu-ragu, berhenti, memperlihatkan, memperhatikan, meletakan, mengatakan, mengabdi, memahami, mencegah,

8 Rachmadi Usman, Hukum Perwakafan di Indonesia (Sinar Grafika, 2009), 132.

9 Abdurrahman, Masalab Perwakafan Tanah Milik dan Kedudukan Tanah Wakaf di Negara Kita (Citra Aditya Bakti, 1994), 15. menahan, dan tetap berdiri ${ }^{10}$. Kata al-waqf adalah bentuk kata kerja dari ungkapan waqfu al-syai yang berarti menahan sesuatu. Dalam pengertian secara umum wakaf adalah pemberian yang pelaksanaannya dilakukan dengan jalan menahan (pemilikan) asal (tabbisul ashli), lalu menjadikan manfaatnya berlaku umum. Sedangkan yang dimaksud dengan tabbisul ashli ialah menahan barang yang diwakafkan itu agar tidak diwariskan, disewakan dan digadaikan kepada orang lain. Cara pemanfaatanya, menggunakannya adalah sesuai dengan kehendak pemberi wakaf (wakif) tanpa imbalan ${ }^{11}$.

Wakaf menurut istilah berarti menahan harta yang dapat diambil manfaatnya tanpa musnah seketika dan untuk penggunaan yang mubah, serta dimaksudkan untuk mendapatkan keridhaan Allah S.W.T ${ }^{12}$. Pengertian wakaf jika ditinjau dari segi terminologis ada beberapa konsep, dimana para pakar hukum Islam memiliki pendapat yang berbeda-beda sesuai dengan faham dari mazhab yang dianutnya.$^{13}$

Sedangkan menurut Peraturan Pemerintah Nomor 28 Tahun1977 tentang Perwakafan Tanah Milik Pasal 1 ayat (1), bahwa wakaf adalah perbuatan hukum seseorang atau badan hukum yang memisahkan sebagian dari harta kekayaannya yang berupa tanah milik dan melembagakannya untuk selama-lamanya untuk kepentingan peribadatan atau keperluan umum lainnya sesuai dengan ajaran agama Islam. Dalam Instruksi Presiden Nomor 1 Tahun 1991 tentang Kompilasi Hukum Islam (Buku III Hukum Perwakafan) Pasal 215 ayat (1), bahwa wakaf adalah perbuatan hukum seseorang atau kelompok orang atau badan hukum yang memisahkan sebagian dari benda miliknya dan melembagakannya untuk selamalamanya guna kepentingan ibadat atau keperluan umum lainnya sesuai dengan ajaran Islam.

Dalam Undang-Undang Nomor 41 Tahun 2004 tentang Wakaf Pasal 1 ayat (1), bahwa yang

10 Farida Prihatini, Uswatun Hasanah, dan Wirdyaningsih, Hukum Islam: Zakat dan Wakaf: Teori dan Prakteknya di Indonesia (Diterbitkan atas kerjasama Papas Sinar Sinanti dengan Badan Penerbit Fakultas Hukum Universitas Indonesia, 2005), 108-9.

11 Wakaf dan Islam, "Paradigma Baru Wakaf di Indonesia," 1-2.

12 Ahmad Azhar Basyir, Hukum Islam tentang Wakaf, Ijarah, Syirkah (PT Alma'arif, 1977), 1-5.

13 Abdul Manan, Hukum Wakaf Dalam Paradigma baru di Indonesia, V aria Peradilan, No 255 Februari 2007, Jakarta, 32. 
dimaksud dengan wakaf adalah perbuatan hukum wakif untuk memisahkan dan/atau menyerahkan sebagian harta benda miliknya untuk dimanfaatkan selamanya atau untuk jangka waktu tertentu sesuai dengan kepentingannya guna keperluan ibadah dan/atau kesejahteraan umum menurut syariah.

Sedangkan menurut Kompilasi Hukum Islam Pasal 251 ayat (1) Bab I Buku III, wakaf adalah perbuatan hukum seseorang atau sekelompok orang atau badan hukum yang memisahkan sebagian harta benda miliknya dan melembagakannya untuk selama-lamanya guna kepentingan ibadah atau keperluan umum lainnya sesuai dengan ajaran Islam.

Dari pengertian di atas ada beberapa hal yang perlu diketahui terlebih dahulu, yaitu ${ }^{14}$ :

1. Wakaf benda, adalah benda yang diwakafkan bersifat tahan lama, dimaksudkan bagi setiap benda dalam ketahanannya selama digunakan, baik hasil yang diberikan oleh benda itu maupun kegunaan yang dapat dinikmati sebagai sesuatu yang tidak habisdalam waktu singkat.

2. Wakaf manfaat, adalah benda yang tidak habis dalam waktu singkat itu dapat dimanfaatkan dalam berbagai bidang sesuai fungsinya. Dan dalam menggunakan benda itu ada makna kebaikan bagi kehidupan agama. Manfaatnya dapat dirasakan oleh banyak orang dan tidak bertentangan dengan kehendak Allah SWT.

Wakaf produktif adalah harta benda atau pokok tetap yang diwakafkan untuk dipergunakan dalam kegiatan produksi dan hasilnya di salurkan sesuai dengan tujuan wakaf. Seperti wakaf tanah untuk digunakan bercocok tanam, mata air untuk diambil airnya dan lain- lain ${ }^{15}$. Atau wakaf produksi juga dapat didefenisikan yaitu harta yang digunakan untuk kepentingan produksi baik dibidang pertanian, Perindustrian, perdagangan dan jasa yang menfaatnya bukan pada benda wakaf secara langsung, tetapi dari keuntungan bersih dari hasil pengembangan wakaf yang diberikan kepada orang -orang yang berhak sesuai dangan tujuan wakaf.

Wakaf produktif adalah sebuah skema pengelolaan donasi wakaf dari umat, yaitu dengan memproduktifkan donasi tersebut, hingga mampu menghasilkan surplus yang berkelanjutan. Donasi wakaf dapat berupa benda bergerak, seperti uang dan logam mulia, maupun benda tidak bergerak,

${ }^{14}$ R. Abdul Djamali, Hukum Islam: Berdasarkan Ketentuan Kurikulum Konsorsium Ilmu Hukum (Mandar Maju, 2002), 183.

15 Mundzir Qahaf dan H. Muhyiddin Mas Rida, Manajemen Wakaf Produktif (Khalifa, 2007), 5. seperti tanah dan bangunan. Pada dasarnya wakaf itu produktif dalam arti harus menghasilkan karena wakaf dapat memenuhi tujuannya jika telah menghasilkan dimama hasilnya dimanfaatkan sesuai dengan peruntukannya (mauquf alaih). Orang yang pertama melakukan perwakafan adalah Umar bin al Khaththab mewakafkan sebidang kebun yang subur di Khaibar. Kemudian kebun itu dikelola dan hasilnya untuk kepentingan masyarakat ${ }^{16}$. Tentu wakaf ini adalah wakaf produktif dalam arti mendatangkan aspek ekonomi dan kesejahteraan masyarakat. Ironinya, di Indonesia banyak pemahaman masyarakat yang mengasumsikan wakaf adalah lahan yang tidak produktif bahkan mati yang perlu biaya dari masyarakat, seperti kuburan, masjid dan lain-lain.

Dalam pengelolaan harta wakaf produktif, pihak yang paling berperan berhasil atau tidaknya dalam pemanfaatan harta wakaf adalah Nazhir wakaf, yaitu seseorang atau kelompok orang dan badan hukum yang diserahi tugas oleh wakif (orang yang mewakafkan harta) untuk mengelola wakaf. Walaupun dalam kitab-kitab fikih ulama tidak mencantumkan Nazhir wakaf sebagai salah satu rukun wakaf, karenaa wakaf merupakan ibadah tabarru' (pemberian yang bersifat sunnah). Namun demikian, setelah memperhatikan tujuan wakaf yang ingin melestarikan manfaat dari hasil harta wakaf, maka keberadaan Nazhir sangat dibutuhkan, bahkan menempati pada peran sentral. Sebab dipundak Nazhir lah tanggung jawab dan kewajiban memelihara, menjaga dan mengembangkan wakaf serta menyalurkan hasil atau manfaat dari wakaf kepada sasaran wakaf. Kemampuan mengolah tanah yang minim. Di samping karena faktor letak yang tidak strategis secara ekonomi dan kondisi tanah yang gersang, hambatan yang cukup mencolok untuk mengolah tanah wakaf secara produktif adalah kemampuan Sumber Daya Manusia (SDM), kondisi ini banyak di alami oleh para Nazhir wakaf yang ada di pedesaan di hampir seluruh pelosok nusantara, bahwa kemampuan menggarap masih sangat minim ${ }^{17}$.

Di samping kendala teknis tanah yang tidak strategis secara ekonomis, di dalam masyarakat kita masih terjadi prokontra pengalihan atau pertukaran tanah wakaf untuk tujuan yang produktif maupun pemanfaatannya. Misalnya, ada seorang wakif yang mewakafkan tanah kebunnya untuk pesantren di pusat kota, sementara tanah

\footnotetext{
${ }^{16}$ Qahaf dan Rida, 5.

${ }^{17}$ Qahaf dan Rida, 5.
} 
yang wakif miliki di pedesaan jauh dari pesantren tersebut. Sementara pesantren tidak memiliki modal yang cukup untuk mengelola tanah wakaf tersebut, sehingga tanah wakaf seperti itu tidak bisa di kelola secara baik karena kendala transportasi dan sarana lain. Namun ketika para wakif di tawarkan bahwa tanah wakaf tersebut sebaiknya dijual dan hasil penjualan untuk kepentingan pesantren seperti gedung perpustakaan misalnya, ternyata para wakif banyak yang menolaknya karena memegangi paham bahwa wakaf tidak bisa di jual.

Adapun fungsi wakaf Dalam Peraturan Pemerintah Nomor 28 Tahun 1977 tentang Perwakafan Tanah Milik pasal 2 dan Instruksi Presiden Nomor 1 Tahun 1991 tentang Kompilasi Hukum Islam (Buku III tentang Hukum Perwakafan) pasal 216 menyebutkan, bahwa fungsi wakaf adalah mengekalkan manfaat benda wakaf sesuai dengan tujuan wakaf, yaitu melembagakannya untuk selama-lamanya guna kepentingan ibadat atau keperluan umum lainnya sesuai dengan ajaran Islam. Tujuan wakaf yang dimaksud oleh Undang-Undang Nomor 41 Tahun 2004 tentang Wakaf dijelaskan pada pasal 4, bahwa wakaf bertujuan untuk memanfaatkan harta benda wakaf sesuai dengan fungsinya. Dalam rangka mencapai tujuan dan fungsi wakaf ditambahkan dalam pasal 22, bahwa harta benda wakaf hanya dapat diperuntukkan bagi; sarana dan kegiatan ibadah sarana dan kegiatan pendidikan serta kesehatan; bantuan kepada fakir miskin, anak terlantar, yatim piatu, beasiswa; kemajuan dan peningkatan ekonomi umat; dan/atau kemajuan kesejahteraan umum lainnya yang tidak bertentangan dengan syariah dan peraturan perundang-undangan.

Sebagaimana dimaksud dalam pasal 22, penetapan peruntukan harta benda wakaf dilakukan oleh wakif pada saat pelaksanaan ikrar wakaf. Sedangkan dalam hal wakif tidak menetapkan peruntukkan harta benda wakaf, nazhir dapat menetapkan peruntukkan harta benda wakaf yang dilakukan sesuai dengan tujuan dan fungsi wakaf. Dalam Undang-Undang Nomor 41 Tahun 2004 tentang Wakaf pasal 5 dijelaskan bahwa fungsi wakaf adalah mewujudakan potensi dan manfaat ekonomis harta benda wakaf untuk kepentingan ibadah dan untuk memajukan kesejahteraan umum. Wakaf merupakan tindakan hukum sukarela yang amat dianjurkan sebagai manifestasi rasa syukur atas anugerah rezeki yang diterima oleh seseorang dan difungsikan untuk kepentingan sosial dan keagamaan.

Dalam pelaksanaannya, agar fungsi wakaf sesuai dengan tujuan wakaf, maka objek wakaf hendaknya didayagunakan dengan sebaik-baiknya dalam pengelolaannya. Untuk itu diperlukan nazhir yang profesional dibidangnya dengan mengedepankan prinsip dan ajaran Islam. Dengan adanya nazhir yang profesioanal tersebut diharapkan objek wakaf yang masih banyak terbengkalai serta belum optimal pemanfaatannya dapat lebih produktif, sehingga dapat memberikan sumbangan bagi kesejahteraan masyarakat dan pembangunan bangsa serta dapat mencegah timbulnya permasalahan atau sengketa yang dapat timbul di kemudian hari.

\section{Status Hukum Terhadap Wakaf Produktif Dalam Telaah Undang-Undang Nomor 41 Tahun 2004 Tentang Wakaf}

Wakaf merupakan salah satu tuntunan ajaran Islam yang menyangkut kehidupan bermasyarakat dalam rangka ibadah ijtima"iyah (ibadah sosial). Karena wakaf adalah ibadah, maka tujuan utamanya adalah pengabdian kepada Allah SWT dan ikhlas karena mencari ridha-Nya ${ }^{18}$. Salah satu alasan pembentukan Undang-Undang Nomor 41 Tahun 2004 tentang Wakaf adalah praktik wakaf yang ada di masyarakat belum sepenuhnya berjalan tertib dan efisien, salah satu buktinya adalah di antara harta benda wakaf tidak terpelihara dengan baik, terlantar, bahkan beralih ke tangan pihak ketiga dengan cara melawan hukum ${ }^{19}$.

Dalam sejarah Islam, wakaf dikenal sejak masa Rasulullah SAW karena wakaf disyariatkan pada tahun kedua Hijriyah ${ }^{20}$. Ada dua pendapat yang berkembang di kalangan ahli yurisprudensi Islam (fuqaba) tentang siapa yang pertama kali melaksanakan syariat wakaf. Menurut sebagian pendapat ulama mengatakan bahwa yang pertama kali melaksanakan wakaf adalah Rasulullah SAW yaitu wakaf tanah milik Nabi SAW untuk dibangun masjid. Sebagian ulama menyatakan bahwa yang pertama kali melaksanakan syariat wakaf adalah Umar bin Khatab. Pendapat ini berdasarkan hadits yang diriwayatkan Ibnu Umar ra, sebagaimana telah dikemukakan di atas.

Praktek wakaf juga berkembang luas pada masa dinasti Umayyah dan dinasti Abbasiyah dan

18 Abdul Ghofur Anshori, "Hukum dan Praktik Perwakafan di Indonesia," Yogyakarta: Pilar Media, 2005, 1.

19 Jaih Mubarok, Wakaf Produktif (Simbiosa Rekatama Media, 2008), 58.

20 Direktorat Pemberdayaan Wakaf dan Direktorat Jenderal Bimbingan Masyarakat Islam, "Pedoman Pengelolaan Wakaf Uang," Jakarta: Kementrian Agama, 2008, 6 . 
dinasti sesudahnya, banyak orang berduyun-duyun untuk melaksanakan wakaf, dan wakaf tidak hanya untuk orang-orang fakir dan miskin saja, tetapi wakaf menjadi modal untuk membangun lembaga pendidikan, membangun perpustakaan dan membayar gaji para statnya, gaji para guru dan beasiswa untuk para siswa dan mahasiswa. Antusiasme masyarakat kepada pelaksanaan wakaf telah menarik perhatian negara untuk mengatur pengelolaan wakaf sebagai sektor untuk membangun solidaritas sosial dan ekonomi masyarakat ${ }^{21}$.

Di Indonesia, kegiatan wakaf dikenal seiring dengan perkembangan dakwah Islam di Indonesia. Di samping melakukan dakwah Islam, para ulama juga sekaligus memperkenalkan ajaran wakaf. Hal ini terbukti dari banyaknya masjid-masjid yang bersejarah dibangun di atas tanah wakaf. Ajaran wakaf ini terus berkembang di Indonesia, baik pada masa dakwah pra kolonial, masa kolonial, maupun pasca colonial pada masa Indonesia merdeka.

Hal ini terlihat dari kenyataan bahwa lembaga wakaf yang berasal dari agama Islam ini telah diterima (diresepsi) menjadi hukum adat bangsa Indonesia sendiri. Masa pemerintahan kolonial merupakan momentum kegiatan wakaf. Karena pada masa itu, perkembangan organisasi keagamaan, sekolah, madrasah, pondok pesantren, masjid, semuanya merupakan swadaya dan berdiri di atas tanah wakaf. Namun, perkembangan wakaf kemudian hari tak mengalami perubahan yang berarti. Kegiatan wakaf dilakukan terbatas untuk kegiatan keagamaan, seperti pembangunan masjid, mushalla, langgar, madrasah, perkuburan, sehingga kegiatan wakaf di Indonesia kurang bermanfaat secara ekonomis bagi rakyat banyak.

Walaupun beberapa aturan telah dibuat oleh pemerintah terkait dengan mekanisme wakaf, seperti PP Nomor 28 Tahun 1977 Tentang Perwakafan Tanah Milik, akan tetapi PP ini hanya mengatur wakaf pertanahan saja. Ini berarti tak jauh beda dengan model wakaf pada periode awal, identik dengan wakaf tanah, dan kegunaannya pun terbatas pada kegiatan social keagamaan, seperti masjid, kuburan, madrasah, dan lain-lain. Karena minimnya regulasi yang mengatur tentang perwakafan, maka tidaklah heran jika perkembangan wakaf di Indonesia mengalami stagnasi. Stagnasi perkembangan wakaf di Indonesia mulai mengalami dinamisasi ketika pada tahun 2001, beberapa praktisi ekonomi Islam

\footnotetext{
${ }^{21}$ Wakaf dan Islam, 8.
}

mulai mengusung paradigma baru ke tengah masyarakat mengenai konsep baru pengelolaan wakaf uang untuk peningkatan kesejahteraan umat. Ternyata konsep tersebut menarik dan mampu memberikan energy untuk menggerakkan kemandegan perkembangan wakaf. Kemudian pada tahun 2002, Majelis Ulama Indonesia (MUI) menyambut konsep tersebut dengan mengeluarkan fatwa yang membolehkan wakaf uang (waqf alnuqud).

Fatwa MUI tersebut kemudian diperkuat oleh hadirnya Undang-Undang No. 41 Tahun 2004 Tentang Wakaf yang menyebutkan bahwa wakaf tidak hanya benda tidak bererak, tetapi juga dapat berupa benda bergerak, seperti uang. Selain itu, diatur pula kebijakan perwakafan di Indonesia, mulai dari pembentukan nadzir sampai dengan pengelolaan harta wakaf. Untuk dapat menjalankan fungsinya, Undang-Undang ini masih memerlukan perangkat lain yaitu Peraturan Pemerintah dan Peraturan Menteri Agama tentang Wakaf Uang yang akan menjadi juklak dalam implementasinya, serta adanya Badan Wakaf Indonesia (BWI) yang akan berfungsi sebagai sentral nadzir wakaf. Setelah melalui proses panjang, pada penghujung tahun 2006 terbitlah Peraturan Pemerintah No. 42 Nomor 2006 Tentang Pelaksanaan Undang-Undang Wakaf.

Wakaf di Indonesia adalah identik dengan tanah, di mana wakaf memiliki kedudukan penting dalam membangun kesejahteraan umat Islam. Walaupun demikian, tidak banyak umat Islam Indonesia yang menyadarinya. Jika disejajarkan dengan instrument filantropi lain dalam Islam, masyarakat Indonesia lebih mengenal dengan zakat, infak, dan sedekah (ZIS) dibanding dengan wakaf. Sebab, selama ini wakaf dikategorikan sebagi masalah ibadah atau kepemilikan Allah, akibatnya wakaf tidak boleh dikembangkan secara ekonomis. Padahal, wakaf adalah sangat strategis untuk pemberdayaan masyarakat, pembangunan ekonomi bangsa, dan kesejahteraan sosial.

Dinamika praktik wakaf di Indonesia, baik dari sisi konsepsional maupun institusional, tak lepas dari dinamika Islam maupun dinamika konteks dan kebutuhan masyarakat di zamannya. Pada awal penyiaran dan perkembangan islam, wakaf identik dengan kebutuhan ibadah dan dakwah sehingga kegiatan wakaf yang Nampak adalah terbatas dan terformat pada orientasi kegiatan keagamaan, seperti pembangunan masjid, mushalla, madrasah, perkuburan dan sarana ibadah lainnya. Menurut Gibb dan Kramers, meskipun sepanjang sejarah Islam wakaf telah memainkan peranan yang sangat penting dalam pembangunan 
masyarakat muslim, tetapi banyak pengelolaan wakaf tidak selalu mencapai hasil yang diinginkan.

Wakaf merupakan modal (capital) umat Islam yang sangat potensial, bila dikelola dan dikembangkan dengan manajemen yang baik. Wakaf berfungsi sebagai factor produksi bagi perkembangan ekonomi yang diperuntukkan bagi kesejahteraan umat Islam. Jumlah tanah wakaf di Indonesia hingga tahun 1991 mencapai 319.214 lokasi ${ }^{22}$. Karena itu, wajar saja bila pemerintah sejak zaman Belanda hingga sekarang menaruh perhatian yang besar dan menetapkan berbagai peraturan dan perundang-undangan sebagai kontrol terhadap pengelolaan wakaf.

Muhammad Musa al-Tiwana membagi ijtihad itu ke dalam tiga objek: pertama, ijtihad dalam rangka memberi penjelasan dan penafsiran terhadap nash. Kedua, ijtihad dalam melakukan terhadap hukum-hukum yang telah ada dan disepakati. Ketiga, ijtihad dalam arti penggunaan ra'y. ${ }^{23}$ Para fukaha yang berijtihad terhadap nashnash yang zhanni, melakukan ta'wîl sebagai metodenya. Ta'wîl dalam Ushul Fiqih diartikan sebagai "Mengeluarkan lafaz dari makna labirnya kepada makna lain yang memungkinkan, di mana makna tersebut, tidak termasuk makna labirnya". Bagi Abû Zahrah ta'wîl termasuk aspek-aspek istinbâth yang piawai dalam menangani masalah hukum. Ijtihad telah terbukti ampuh dalam menyelesaikan persoalan-persoalan baru yang dihadapi umat Islam. Sejak masa awal sampai masa keemasannya, ijtihad mampu menyelesaikan masalah-masalah yang tidak terdapat dalam al-Qur'an dan Hadis. Ijtihad telah menjadi daya gerak kemajuan umat Islam dalam segala bidang termasuk bidang hukum.

Berbagai persoalan kontemporer yang muncul ke permukaan yang menyangkut berbagai bidang kehidupan seperti ekonomi, sosial, budaya, kesehatan, merupakan masalah-masalah yang harus dikaji hukumnya melalui ijtihad dengan merujuk pada jiwa hukum yang terkandung dalam al-Qur'an dan Hadis (maqâshid al-syarî́at). Islam bertujuan untuk menciptakan suatu tata sosiopolitik di atas landasan etika dan moral yang kuat dalam rangka mengaktualisasikan prinsip rahmatan lil âlamîn dalam ruang dan waktu. Fondasi moral dan etika ini merupakan pra syarat bagi

\footnotetext{
22 Abdul Halim dan Mhd Rasidin, Hukum Perwakafan di Indonesia (Ciputat Press, 2005), 149.

23 Muhammad Musa al-Tiwana, al-Ijtihâd wa Madâ Hajâtinâ Ilaibi fì hâdz̧â al-'Asr, (Mesir: Dâr Kutub alHaditsah), 39.
}

pembentukan apa yang diistilahkan dalam alQur'an sebagai khoir ummah, yaitu suatu tatanan sosio-politik-kultur yang kebaikan dan kualitasnya dapat diukur secara obyektif dan dengan standar apa pun.

Indonesia terdapat lebih kurang 15 (lima belas) perangkat perundang-undangan wakaf yang telah diberlakukan. Undang-undang wakaf dimasukkan ke dalam Kompilasi Hukum Islam (KHI) pada Buku III sejak tahun 1991, namun masih terbatas pada perwakafan tanah milik. Adapun pengaturan benda bergerak sebagai harta wakaf seperti uang, logam mulia, surat berharga, kenderaan, hak atas kekayaan intelektual, hak sewa dan lain-lain belum termuat secara rinci hingga diberlakukannya Undang-Undang RI Nomor 41 Tahun 2004 tentang Wakaf. Hal ini memberi indikasi bahwa harta wakaf lebih ditingkatkan pada pengelolaan dan pengembangan yang berorientasi produktif.

Wakaf Produktif pada umumnya berupa tanah pertanian atau perkebunan, gedung-gedung komersial, dikelola sedemikian rupa sehingga mendatangkan keuntungan yang sebagian hasilnya dipergunakan untuk membiayai berbagai kegiatan tersebut. Sehingga dengan demikian harta wakaf benarbenar menjadi sumber dana dari masyarkat untuk masyarakat ${ }^{24}$.

Salah satu bentuk wakaf produktif dalam ijtihad ulama masa kini adalah bentuk wakaf wakaf produktif atau lebih juga disebut dengan istilah wakaf uang belum lama dikenal di Indonesia. Padahal wakaf uang tersebut sebenarnya sudah cukup lama dikenal di dunia Islam, yakni sejak zaman kemenangan dinasti mamluk, para ahli fikih memperdebatkan boleh atau tidaknya uang, diwakafkan. Ada sebagian ulama yang membolehkan wakaf uang, dan sebagian ulama melarangnya, dan masing-masing mempunyai alasan yang memadai. Meskipun wakaf uang sudah dikenal pada masa Imam Mazhab, namun wakaf uang baru akhirakhir ini mendapat perhatian para ilmuan dan menjadi bahan kajian intensif. Di berbagai Negara, Wakaf Uang sudah lama menjadi kajian, dan bahkan sudah dipraktekkan serta diatur dalam peraturan perundang-undangan.Yang menjadi masalah di berbagai tempat baik di Indonesia maupun di Negara lain adalah pengelolaannya, tidak jarang wakaf dikelola dengan manajemen yang kurang bagus sehingga dapat mengakibatkan wakaf tersebut berkurang atau

\footnotetext{
${ }^{24}$ Muhammad Yusuf, "Pemberdayaan Wakaf Produktif Untuk Pemberdayaan Ekonomi Umat," Semarang: Badan Wakaf Nusantara, 2009, 40.
} 
hilang. Padahal, jika wakaf uang ini diatur, dikelola, dan dikembangkan dengan baik akan membawa dampak yang begitu besar dalam masyarakat ${ }^{25}$.

Perlu dapat dipahami bahwa dasar penetapan wakaf produktif dalam Undang-undang Nomor 41 Tahun 2004 adalah ijtihad. Ijtihad yaitu mencurahkan kemampuan untuk mendapatkan hukum syara' yang bersifat operasional melalui upaya istinbath (penggalian) hukum. Lahirnya Undang-Undang Republik Indonesia No. 41 tahun 2004 tentang Wakaf diarahkan untuk memberdayakan wakaf yang merupakan salah satu instrumen dalam membangun kehidupan sosial ekonomi umat Islam. Kehadiran Undang-undang wakaf ini menjadi momentum pemberdayaan wakaf secara produktif, sebab di dalamnya terkandung pemahaman yang komprehensif dan pola manajemen pemberdayaan potensi wakaf secara modern.

Pemerintah memberikan perhatian yang sangat serius dengan mengeluarkan Peraturan Pemerintah Nomor 42 tahun 2006 tentang Pelaksanaan Undang-Undang Nomor 41 tahun 2004 tentang Wakaf karena selama ini tradisi masyarakat Indonesia khususnya dipedalaman dalam pengelolaan wakaf masih cenderung bersifat konsumtif dan pengelolaan secara produktif yang diharapkan oleh pemerintah belum maksimal. Selain itu juga persepsi masyarakat dalam memahami wakaf masih terikat dan tersekat dengan pemahaman lama yang hampir mendominasi pemikiran masyarakat Muslim Indonesia.

Dasar penetapan wakaf produktif. dalam Undang-undang Nomor 41 Tahun 2004 adalah ijtihad. Ijtihad yaitu mencurahkan kemampuan untuk mendapatkan hukum syara ' yang bersifat operasional melalui upaya istinbath (penggalian) hukum. Undang-Undang 41 Tahun 2004 terdiri dari 11 (sebelas) Bab dan 71 (tujuh puluh satu) Pasal, dengan rincian Bab I, Ketentuan umum, Bab II, Dasar-dasar wakaf, Bab III, mengenai Pendaftaran dan Pengumuman harta wakaf, Bab IV, Perubahan status benda wakaf, Bab V, Pengelolaan dan Pengembangan harta benda wakaf, Bab VI, Badan wakaf Indonesia, Bab VII, Penyelesaian sengketa, Bab VIII, Pembinaan dan Pengawasan, Bab IX, Ketentuan Pidana dan Sanksi administrasi, Bab X, Ketentuan Peralihan dan Bab XI, Ketentuan penutup.

Bab V dalam Undang-Undang 41 Tahun 2004 merupakan pengembangan dari Undang-

25 Wakaf dan Islam, "Pedoman Pengelolaan Wakaf Uang," 93. undang wakaf sebelumnya yang mengatur tentang pengelolaan harta wakaf, dimana kewajiban nazir diatur secara gamblang sesuai dengan prinsip syari'ah dan pada pasal 43 ayat 2 dijelaskan bahwa pengelolaan dan pengembangan harta benda wakaf dilakukan secara produktif.

Kehadiran Undang-Undang Nomor 41 Tahun 2004 tentang Wakaf telah membawa paradigma baru perwakafan di Indonesia. Pasal 42 dan 43 Undang Undang Nomor 41 Tahun 2004 tentang Wakaf tersebut mewajibkan nazir untuk mengelola dan mengembangkan harta benda wakaf sesuai dengan tujuan, fungsi dan peruntukannya dan harus dilakukan secara produktif tanpa melanggar prinsip-prinsip syari'ah. Pengelolaan dan pengembangan secara produktif tersebut antara lain dengan cara pengumpulan (fundraising), investasi, penanaman modal, produksi, kemitraan, perdagangan, agrobisnis, pertambangan, perindustrian, pengembangan teknologi dan pembangunan gedung, apartemen, rusun, pasar swalayan, pertokoan, perkantoran, sarana pendidikan dan usaha-usaha yang tidak bertentangan dengan syari'ah.

Undang-undang Nomor 41 Tahun 2004 Tentang Wakaf ini juga menjadi momentum pemberdayaan wakaf secara produktif sebab di dalamnya terkandung pemahaman yang komprehensif dan pola manajemen pemberdayaan potensi wakaf secara modern. Dalam undangundang wakaf yang baru ini konsep wakaf mengandug dimensi yang sangat luas. Ia mencakup harta tidak bergerak, maupun yang bergerak, termasuk wakaf uang yang penggunaannya sangat luas, tidak terbatas untuk pendirian tempat ibadah dan sosial keagamaan. Undang-undang no 41 tahun 2004 tentang wakaf telah memberikan kepastian hukum serta memberikan dorongan pada masyarakat untuk giat berwakaf khususnya dalam melakukan pengelolaan wakaf secara produktif.

\section{Penerapan Wakaf Produktif Sebagai Perangkat Peningkatan Ekonomi Masyarakat di Indonesia}

Islam menuturkan bahwa setiap manusia sama derajatnya dihadapan Allah oleh karena itu umat manusia dipandang sebagai satu keluarga. Untuk merealisasikan kekeluargan dan kebersaman tersebut, harus ada kerja sama secara sukarela (antaradhin-minkum) dan tolong menolong secara.benar (ta'awanu 'alal bird wa taqwa). Konsep persaudaraan dan perlakuan yang sama terhadap seluruh anggota masyarakat di muka bumi tidaklah mempunyai arti kalau tidak disertai dengan keadilan ekonomi yang memungkinkan 
setiap orang memperoleh hak atas sumbangannya terhadap masyarakat.

Dengan kcmitmen Islam yang khas dan mendalam terhadap persaudaraan, keadilan sosial dan ekonomi, maka ketidakadilan dalam pendapatan dan kekayaan yang berlangsung saat ini adalah bertentangan dengan Islam. Akan tetapi konsep keadilan Islam dalam distribusi pendapatan dan kekayaan serta konsepsinya tentang keadilan sosial tidaklah menuntut bahwa semua orang harus mendapat upah yang sama tanpa memandang konstiibusinya kepada masyarakat. Islam memberikan toleransi ketidaksamaan pendapatan sampai tingkat tertentu, karena setiap orang tidaklah sama sifat, kemampuan dan pelayanannya dalam masyarakat Adanya perpedaan derajat kemampuan serta perbedaan dalam kesempatan dapat menjadi sebab musabab darl perbedaan dalam perolehan rezeki yang mungkin dllerima oleh seseorang. Akibat lebih lanjut adalah lahirnya golongan kaya (qaum agbniaa) dan golongan miskin (qaum duafa'/Masakin) dalam masyarakat, jurang pemisah yang semakin dalam antara keduanya. Dalam al-Qur'an terdapat petunjuk dan pedoman bagi seseorang untuk membelanjakan hartanya, baik untuk kepentingan dirinya sendlri maupun untuk kepentingan orang lain dalam masyarakat.

Petunjuk itu antara lain terdapat dalam surat al-Isra' ayat 26 :

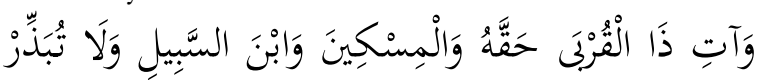

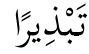

Artinya: "Dan berikanlah bagi keluarga-keluarga yang dekat akan haknya, kepada orang miskin dan orang yang dalam perjalanan; dan janganlah kamu menghambur-bamburkan (bartamu) secara boros". Dan "babkan mengeiuarkan sedekah kepada orang yang membutubkaan berakibat pada kebersiban dan kesucian diri."

Dari uraian tersebut nampak jelasbahwa perekonomian dalam Islam sangat peduli terhadap kaum yang lemah di satu sisi, dan sekaligus mendorong umat untuk bekerja keras. Menurut Monzer Kahf setiap kegiatan ekonomi dalam Islam harus didasarkan pada asas filsafat ekonomi Islam. Adapun asas filsafat ekonomi islam adalah; (1) Semua yang ada di alam semesta, langit, bumi serta sumber alam yang ada padanya, bahkanharta kekayaan yang dimiliki manusia adalah milik Allah. Manusia sebagai khalifah-Nya hanya berhak mengurus dan memanfaatkan alam semesta itu untuk kelangsungan hidup manusia Itu ssndirl dan lingkungannya; (2) Allah Maha Esa, yang menciptakan segala makhluk yang ada di alam semesta ini. Manusia sebagai makhluk Allah diberi alat kelengkapan yang paling sempurna dibanding makhluk lain, agar la mampu melaksanakan tugas, hak dan kewajibannya sebagai khalifah Allah di bumi itu, manusia yang berasal dari substansi yang sama, wajib saling bantu membantu dan bekerjasama terutama dalam melakukan kegiatan ekonomi untuk memenuhi keperiuannya berdasarkan persamaan dan persaudaraan; (3) Beriman kepadahari kiamat. Keyakinan kepada hari kiamat ini sangat panting dalam sistem ekonomi Islam karena dengan keyakinan itu, tingkah laku ekonomi manusia di dunia ini akan dapat terkendali, karena bahwa semua perbuatan, termasuk tindakan ekonomi akan dimintai pertanggungjawabnya di hadapan Allah. ${ }^{26}$

Ekonomi Islam adalah ekonomi yang berdasarkan ketuhanan. Ekonomi Islam bertitik tolak dari Allah, bertujuan akhir kepada Allah, dan menggunakan sarana yang tidak lepas dari syariat Allah ${ }^{27}$. Menurut agama Islam kegiatan ekonomi merupakan bagian dari kehidupan yang menyeluruh, dilandasi oleh nilai-nilai yang bersumber dari alquran dan hadits yang diaplikasikan pada hubungan kepada Allah dan kepada manusia secara bersamaan. ${ }^{28}$ Nilai-nilai inilah yang menjadi sumber ekonomi Islam. ${ }^{29}$ Sehingga kegiatan ekonomi terikat oleh nilai-nilai keislaman, termasuk dalam memenuhi kebutuhan.

Pada hakikatnya, manusia dalam memenuhi kebutuhan sehari-hari, bertujuan untuk memenuhi kelangsungan hidupnya. Di antara kebutuhan yang diperlukan ialah barang dan jasa, yang mampu memberikan manfaat kepada manusia, baik untuk dirinya maupun orang lain. Nilai manfaat inilah yang menjadi salah satu faktor dari kebutuhan manusia atau disebut sebagai nilai ekonomis dalam perspektif ilmu ekonomi. Ilmu ekonomi membagi kebutuhan menjadi tiga, yaitu kebutuhan primer, kebutuhan sekunder, dan kebutuhan tersier.

Berangkat dari asas pokok filsafat ekonomi Islam tersebut di atas, dapat melahirkan nilai nilai dasar sistem ekonomi Islam seperti yang diungkapkan oleh Muhammad Daud Ali. Adapun nilai-nilai dasar sistem ekonomi Islam itu adalah:

\footnotetext{
${ }^{26}$ Ahmad M. Saifuddin, Studi Nilai-Nilai Sistem Ekonomi Islam, (Jakarta: Media Dakwah, 1984), 19.

27 Qardhawi Yusuf, Norma dan Etika Ekonomi Islam, diterjemabkan oleh Zainal Arifin dan Dablia Husain (Jakarta: Gema Insani Press, 1999), 31.

28 Muhammad, Ekonomi Islam, (Malang: Empat Dua, 2009), 135.

29 Muhammad, Prinsip-Prinsip Ekonomi Islam, (Yogyakarta: Graha Ilmu, 2007), 1.
} 
1. Nilai dasar pemilikan. Menurut sistem ekonomi Islam, pemilikan bukanlah penguasaan mutlak atas sumber-sumber ekonomi, tetapi kemampuan untuk memanfatkannya, dan lama pemilikan manusia atas sesuatu benda terbatas pada lamanya manusia itu hidup di dunia ini, dan sumber-sumber daya aiam yang menjadi hajat hidup orang banyak harus menjadi milik umum atau Negara.

2. Nilai keseimbangan. Nilai keseimbangan merupakan nilai dasaryang mempengaruhi berbagai aspek tingkah laku ekonomi seorang muslim. Asas keseimbangan ini misalnya terwujud dalam kesederhanaan, hemat dan merij'auhi keborosan. Nilai dasar keseimbangan ini harus dijaga sebaik-balknya bukan saja antara kepentingan dunia dengan akhirat dalam ekonomi, tetapi juga keseimbangan antara kepentingan perorangan dengan kepentingan umum, serta keseimbangan antara hak dengan kewajiban.

Salah satu lembaga ekonomi islam yang sangat berperan dalam pemberdayaan ekonomi masyarakat Islam adalah wakaf. Dalam sejarah, wakaf telah memerankan peran penting dalam pengembangan sosial, ekonomi, dan budaya masyarakat. Hal-hal yang paling menonjol dari lembaga wakaf adalah peranannya dalam membiayai berbagai pendidikan Islam dan kesehatan. Sebagai contoh misalnya di Mesir, Saudi Arabia, Turki dan beberapa Negara lainnya pembangunan dan berbagai sarana dan prasarana pendidikan dan kesehatan dibiayai dari hasil pengembangan wakaf. Kesinambungan manfaat hasil wakaf dimungkinkan oleh berlakunya wakaf produktif yang didirikan untuk menopang berbagai kegiatan sosial dan keagamaan. Wakaf Produktif pada umumnya berupa tanah pertanian atau perkebunan, gedung-gedung komersial, dikelola sedemikian rupa sehingga mendatangkan keuntungan yang sebagian hasilnya dipergunakan untuk membiayai berbagai kegiatan tersebut. Sehingga dengan demikian harta wakaf benarbenar menjadi sumber dana dari masyarkat untuk masyarakat ${ }^{30}$.

Azyumardi Azra menyebutkan bahwa wakaf terbukti telah memainkan peranan yang signifikan dalam pertumbuhan masyarakat Islam dunia. Hal tersebut terbukti dengan semakin berkembangnya sektor pendidikan, sosial, ekonomi, kesehatan dan kebudayaan. Sebagai contoh, pada masa kekuasaan Daulah Abbasiyah dan Kekaisaran Turki Usmani,

30 Yusuf, "Pemberdayaan Wakaf Produktif Untuk Pemberdayaan Ekonomi Umat," 15. telah berkembang wakaf untuk membiayai pendidikan seperti untuk membangun madrasah dan menyediakan beasiswa ${ }^{31}$. Pada abad ke-10 M, di Iran Selatan telah dibangun jembatan, penginapan murah, dan rumah sakit. Sementara itu di penghujung abad ke-10 M (tahun 991-993 M), di kota Baghdad didirikan perpustakaan ternama yang didedikasikan untuk kepentingan penelitian, perkuliahan, dan pengajaran. ${ }^{32}$ Menurut George Makdisi, pada abad ke-11 $\mathrm{M}$, wakaf telah menghidupi pendidikan dan memiliki orientasi keagamaan dalam masyarakat Islam di kota Baghdad $^{33}$.

Wakaf merupakan ajaran yang tidak hanya berdimensi agama, tetapi juga menekankan pentingnya kesejahteraan Sosial. ${ }^{34} \mathrm{Hal}$ ini sejalan dengan ekonomi Islam yang berhubungan dengan kesejahteraan sosial dan juga berkaitan dengan hubungan kepada Allah. ${ }^{35}$ Masalah wakaf merupakan masalah yang sampai saat ini kurang dibahas secara intensif. Hal ini disebabkan karena umat Islam hampir melupakan kegiatan-kegiatan yang berasal dari lembaga perwakafan. Masalah mis-management dan korupsi diperkirakan menjadi penyebab utama, sehingga kegiatan lembaga perwakafan ini kurang diminati atau bahkan ditinggalkan oleh umat Islam kurang seabad yang lalu ${ }^{36}$.

Wakaf mempunyai peran penting sebagai salah satu instrumen dalam memberdayakan ekonomi umat. Dalam sejarah, wakaf telah memerankan peran penting dalam pengembangan

31 Azyumardi Azra, Jaringan ulama: Timur Tengab dan kepulauan Nusantara abad XVII \& XVIII: akar pembaruan Islam Indonesia (Kencana, 2004), 55-67.

32 Said Amir Arjomand, "Philanthropy, the Law, and Public Policy in the Islamic World Before the Modern Era", dalam Warren F. Ilchman (ed.), Philanthropy in the World's Traditions (USA: Indiana Press, 1998), 109-132. Baca juga: Husam 'Abd al-Mu'ti, "Piety and Profit: The Haramayn Endowments in Egypt (1517-1814)" dalam Pascale Ghazaleh, Held in Trust; Waqf in the Islamic World (Cairo: The American University Press, 2011), 41-70.

33 Syed Khalid Rashid, "Origin and Early History of Waqf and Other Issues," Awqaf Experience in South Asia. New Delbi: Institute of Objective Studies, 2002, 11-28.

${ }^{34}$ Pemberdayaan Wakaf di Indonesia, Jakarta: Departemen Agama RI Direktorat Jendral Bimbingan Masyarakat Islam Direktorat Pemberdayaan Wakaf, 2008, 1.

35 Muhammad, Prinsip-Prinsip Ekonomi Islam, (Yogyakarta, Graha Ilmu, 2007), 1-2.

36 R. I. Departemen Agama, Panduan Pemberdayaan Tanah Wakaf Produktif Strategis di Indonesia (Jakarta, 2006), 45. 
sosial, ekonomi, dan budaya masyarakat. Hal-hal yang paling menonjol dari lembaga wakaf adalah peranannya dalam membiayai berbagai pendidikan Islam dan kesehatan. Kesinambungan manfaat hasil wakaf dimungkinkan oleh berlakunya wakaf produktif yang didirikan untuk menopang berbagai kegiatan sosial dan keagamaan. Wakaf Produktif pada umumnya berupa tanah pertanian atau perkebunan, gedung-gedung komersial, dikelola sedemikian rupa sehingga mendatangkan keuntungan yang sebagian hasilnya dipergunakan untuk membiayai berbagai kegiatan tersebut. Sehingga dengan demikian harta wakaf benarbenar menjadi sumber dana dari masyarkat untuk masyarakat ${ }^{37}$.

Di tengah problem sosial masyarakat Indonesia dan tuntutan akan kesejahteraan ekonomi akhir-akhir ini, keberadaan wakaf uang menjadi sangat strategis. Disamping sebagai salah satu aspek ajaran Islam yang berdimensi spiritual, wakaf uang juga merupakan ajaran yang menekankan pentingnya kesejahteraan ekonomi (dimensi sosial) dan kesejahteraan umat. ${ }^{38}$ Namun istilah wakaf uang belum begitu familiar di tengah masyarakat Indonesia, ini bisa dilihat dari pemahaman masyarakat Indonesia yang memandang wakaf hanya sebatas pada pemberian berbentuk barang tidak bergerak, seperti tanah dan bangunan yang diperuntukkan untuk tempat ibadah, kuburan, pondok pesantren, rumah yatim piatu dan pendidikan semata. Pemanfaatan benda wakaf masih berkisar pada hal-hal yang bersifat fisik, sehingga tidak memberikan dampak ekonomi secara signifikan terhadap kesejahteraan masyarakat. Banyaknya harta benda wakaf yang ada di masyarakat Indonesia belum mampu mengatasi masalah kemiskinan.

Data Departmen Agama (Depag) RI (2010) menyebutkan bahwa jumlah tanah wakaf di Indonesia mencapai 2.171.041.349 $\mathrm{m} 2$ yang tersebar di 414.848 lokasi di seluruh Indonesia. Akan tetapi, tanah wakaf tersebut sebagian besar baru dimanfaatkan untuk kesejahteraan Masjid, surau, kuburan, panti asuhan, yayasan, dan sarana pendidikan dan hanya sebagian kecil yang dikelola ke arah lebih produktif. Hal ini diperkuat dengan hasil penelitian Pusat Bahasa dan Budaya (PBB) UIN Syarif Hidayatullah Jakarta, tahun 2006, terhadap 500 responden nadzir di 11 propinsi.

37 Yusuf, "Pemberdayaan Wakaf Produktif Untuk Pemberdayaan Ekonomi Umat."

38 Direktorat Pemberdayaan Wakaf dan Direktorat Jenderal Bimbingan Masyarakat Islam, 1.
Penelitian itu menunjukkan, harta wakaf lebih banyak bersifat diam (77\%) daripada yang produktif $(23 \%)$. Temuan umum lainnya juga menunjukkan pemanfaatan terbesar harta wakaf adalah Masjid $(79 \%)$ dan lebih banyak berada di wilayah pedesaan $(59 \%)$ daripada perkotaan $(41 \%)$. Sedangkan para nadzir pun tidak terfokus dalam mengelola, mereka mayoritas bekerja sambilan dan tidak diberi upah (84\%), dan yang bekerja secara penuh dan terfokus ternyata amatlah minim $(16 \%)$. Selain itu, wakaf di Indonesia lebih banyak dikelola oleh perseorangan (66\%), daripada organisasi professional (16\%) dan berbadan hukum (18\%). Berarti, tanah wakaf yang demikian besar itu pemanfaatannya masih bersifat konsumtif dan belum dikelola secara produktif..$^{39}$

Pengelolaan wakaf juga terjadi di Negara sekuler Singapura. Dengan penduduk muslim minoritas (lebih kurang 453.000 orang saja) berhasil membangun harta wakaf secara inovatif. Melalui WARESS Investment Pte Ltd telah berhasil mengurus dan membangun harta wakaf secara professional. Diantaranya, membangun apartemen 12 tingkat bernilai sekitar $\$ \$ 62,62$ juta. WARESS juga berhasil membangun proyek perumahan mewah yang diberi nama The Chancery Residence. ${ }^{40}$ Perbandingan tersebut menerangkan bahwa walaupun dengan jumlah ummat muslim yang minoritas tetapi dengan pengelolaan harta wakaf secara optimal maka dapat meningkatkan kesejahteraan masyarakat dan mengurangi tingkat kemiskinan.

Pengelolaan wakaf secara produktif untuk kesejahteraan masyarakat menjadi tuntutan yang tidak bisa dihindari lagi. Apalagi di saat ini negri Indonesia mengalami krisis ekonomi yang memerlukan partisipasi banyak pihak. Lahirnya Undang-Undang Republik Indonesia No. 41 tahun 2004 tentang Wakaf diarahkan untuk memberdayakan wakaf yang merupakan salah satu instrumen dalam membangun kehidupan sosial ekonomi umat Islam. Kehadiran Undang-undang wakaf ini menjadi momentum pemberdayaan wakaf secara produktif, sebab di dalamnya terkandung pemahaman yang komprehensif dan pola manajemen pemberdayaan potensi wakaf secara modern.

Undang-Undang Republik Indonesia No. 41 tahun 2004 tentang Wakaf mencakup harta tidak

39 M.Cholil Nafis, Potensi Wakaf Produktif Untuk Kesejahteraan Umat, (Pontianak: Fakultas Syariah dan Ekonomi Islam, 2014), 3.

40 Ibid. 
bergerak maupun yang bergerak, termasuk wakaf uang yang penggunaannya sangat luas, tidak terbatas untuk pendirian tempat ibadah dan social keagamaan. Formulasi hukum yang demikian, jelas suatu perubahan yang sangat revolusioner dan jika dapat direalisasikan akan memiliki akibat yang berlipat ganda atau multiplier effect, terutama dalam kaitannya dengan pemberdayaan ekonomi umat Islam. Namun, usaha ke arah itu jelas bukan pekerjaan yang mudah. Umat Islam Indonesia selama ratusan tahun sudah terlanjur mengidentikkan wakaf dengan (dalam bentuk) tanah, dan benda bergerak yang sifatnya bendanya tahan lama. Dengan demikian, Undang-Undang Nomor 41 tahun 2004 tentang Wakaf diproyeksikan sebagai sarana rekayasa sosial (social engineering), melakukan perubahan-perubahan pemikiran, sikap dan perilaku umat Islam agar senafas dengan semangat Undang-Undang tersebut ${ }^{41}$.

Wakaf produktif pada dasarnya merupakan implementasi tujuan wakaf yaitu kemaslahatan/ kesejahteraan masyarakat melalui model-model usaha ekonomi yang produktif, sehingga manfaat dari harta wakaf dapat berdaya guna secara optimal dan berkesinambungan. Untuk merealisasikan wakaf produktif maka paling tidak harus mempertimbangkan empat azas, yaitu asas keabadian manfaat, asas pertanggung-jawaban, asas profesionalitas managemen, dan asas keadilan sosial. Selain itu empat aspek yaitu pembaharuan paham tentang wakaf, pengembangan sistem manajemen pengelolaan wakaf, sistem manajemen kenadziran dan sistem rekruitmen wakif harus dikembangkan secara proporsional.

Dengan demikian, wakaf produktif dapat memanfaatan tanahtanah wakaf untuk kegiatankegiatan ekonomi bernilai tinggi. Atau dilakukan dengan cara wakaf tunai kepada lembaga ekonomi produktif yang amanah untuk kemudian diinvestasikan untuk menciptakan lapangan kerja. Untuk kemajuan pengembangan wakaf, UndangUndang Nomor 41 Tahun 2004 Tentang Wakaf mengamanahkan pembentukan badan independen yaitu Badan Wakaf Indonesia (BWI). BWI adalah lembaga negara non struktural dan non fungsional yang dibentuk dengan Undang-Undang Nomor 41 Tahun 2004 dan Peraturan Pemerintah No 42 Tahun 2006 dengan tugas untuk membina nadzir dalam pengelolaan dan pengembangan harta benda wakaf, mengelola dan mengembangkan harta benda wakaf berskala nasional dan

41 Satjipto Rahardjo, Hukum dan masyarakat (Angkasa, 1980), 117. international dan lain-lain yang untuk pelaksanaannya dapat bekerja sama dengan instansi pemerintah, badan internasional,organisasi masyarakat, para ahli atau profesional dan lain-lain (pasal 49 ayat 1 dan 2). Sayangnya Badan Wakaf Indonesia ini baru terbentuk pada tahun 2006, dan saat ini baru melakukan konsolidasi organisasi.

Berkaca pada pengembangan wakaf di berbagai negara, tampak bahwa wakaf telan menjadi instrumen sosial ekonomi yang telah memberikan kontribusi dalam pembangunan pendidikan, social ekonomi dan kebudayaan. Di Yordania misalnya, wakaf dikelola oleh kementrian wakaf dan urusan agama Islam. Di samping memelihara dan mengembangkan tempat-tempat ibadah, wakaf ditujukan untuk memperkokoh semangat jihad, menguatkan jiwa Islam dan akhlak Islam, menggalakan pendidikan sampai tujuan melahirkan kebudayaan baru Islam.

\section{Kesimpulan}

1. Wakaf merupakan salah satu tuntunan ajaran Islam yang menyangkut kehidupan bermasyarakat dalam rangka ibadah ijtima"iyah (ibadah sosial). Karena wakaf adalah ibadah, maka tujuan utamanya adalah pengabdian kepada Allah SWT dan ikhlas karena mencari ridha- Nya. Salah satu alasan pembentukan Undang-Undang Nomor 41 Tahun 2004 tentang Wakaf adalah praktik wakaf yang ada di masyarakat belum sepenuhnya berjalan tertib dan efisien, salah satu buktinya adalah di antara harta benda wakaf tidak terpelihara dengan baik, terlantar, bahkan beralih ke tangan pihak ketiga dengan cara melawan hukum. Dasar penetapan terhadap status hukum wakaf produktif. dalam Undang-undang Nomor 41 Tahun 2004 adalah ijtihad. Ijtihad yaitu mencurahkan kemampuan untuk mendapatkan hukum syara' yang bersifat operasional melalui upaya istinbath (penggalian) hukum. Undangundang 41 Tahun 2004 terdiri dari 11 (sebelas) Bab dan 71 (tujuh puluh satu) Pasal. Bab V dalam Undang-Undang 41 Tahun 2004 merupakan pengembangan dari Undangundang wakaf sebelumnya yang mengatur tentang pengelolaan harta wakaf, dimana kewajiban nazir diatur secara gamblang sesuai dengan prinsip syari'ah dan pada pasal 43 ayat 2 dijelaskan bahwa pengelolaan dan pengembangan harta benda wakaf dilakukan secara produktif. Undang-undang Nomor 41 Tahun 2004 Tentang Wakaf ini juga menjadi momentum pemberdayaan wakaf secara produktif sebab di dalamnya terkandung pemahaman yang komprehensif dan pola 
manajemen pemberdayaan potensi wakaf secara modern.

2. Wakaf mempunyai peran penting sebagai salah satu instrumen dalam memberdayakan ekonomi umat. Dalam sejarah, wakaf telah memerankan peran penting dalam pengembangan sosial, ekonomi, dan budaya masyarakat. Hal-hal yang paling menonjol dari lembaga wakaf adalah peranannya dalam membiayai berbagai pendidikan Islam dan kesehatan. Kesinambungan manfaat hasil wakaf dimungkinkan oleh berlakunya wakaf produktif yang didirikan untuk menopang berbagai kegiatan sosial dan keagamaan. Pengelolaan wakaf secara produktif untuk kesejahteraan masyarakat menjadi tuntutan yang tidak bisa dihindari lagi. Apalagi di saat ini negri Indonesia mengalami krisis ekonomi yang memerlukan partisipasi banyak pihak. Lahirnya Undang-Undang Republik Indonesia No. 41 tahun 2004 tentang Wakaf diarahkan untuk memberdayakan wakaf yang merupakan salah satu instrumen dalam membangun kehidupan sosial ekonomi umat Islam. Wakaf produktif pada dasarnya merupakan implementasi tujuan wakaf yaitu kemaslahatan/ kesejahteraan masyarakat melalui model-model usaha ekonomi yang produktif, sehingga manfaat dari harta wakaf dapat berdaya guna secara optimal dan berkesinambungan. Untuk merealisasikan wakaf produktif maka paling tidak harus mempertimbangkan empat azas, yaitu asas keabadian manfaat, asas pertanggung-jawaban, asas profesionalitas managemen, dan asas keadilan sosial.

\section{Daftar Pustaka}

Abdurrahman, Masalah Perwakafan Tanah Milikdan Kedudukan Tanah Wakaf di Negara Kita, Bandung: Citra Aditya Bakti, Bandung, 1994.

Ahmad Rofiq, Hukum Islam di Indonesia Jakarta: PT. Raja Grafindo Persada, 2000.

Ahmad Djunaedi dkk, Pedoman Pengelolaan \& Pengembangan Wakaf Jakarta: Direktorat Jenderal Bimbingan Masyarakat Islam dan Penyelenggaraan Haji. 200

Ahmad Djunaedi dkk., Paradigma Baru Wakaf di Indonesia, Jakarta: Direktorat Pengembangan Zakat dan Wakaf Direktorat Jenderal Bimbingan Masyarakat Islam dan Penyelenggaraan Haji. 2004.

Al-Syaukani, Nail al-Authar, Mesir: Musthafa alBaby al-Halabi
Achmad Djunaidi dan Thobieb Al-Asyhar, Menuju Era Wakaf Produktif, Depok: Mumtaz Publishing, 2007.

Abdul Ghofur Anshori, Hukum dan Praktik Perwakafan di Indonesia, Yogyakarta: Pilar Media, 2005.

Ahmad Azhar Basyir, Wakaf; Izarah dan Syirkah. PT. Al Ma'rifat : Bandung 1987.

Adiwarman A Karim, Berderma untuk semua : Wacana dan praktik Filantropi Islam . Jakarta: Teraju, 2003.

Abdul Halim, Hukum Perwakafan di Indonesia Jakarta: Ciputat Press, 2005.

Bahder Johan Nasution, Metode Penelitian Ilmu Hukum, Bandung : Penerbit CV. Mandar Maju, 2008.

Biro Perbankan Syari'ah BI 2001, 'Peranan Perbankan Syari'ah dalam Wakaf Tunai (Sebuah Kajian Konseptual)' dalam Wakaf Tunai Inovasi Finansial Islam, Jakarta : PSTTTI-UI, 2006.

Budi Harsono, Hukum Agraria Indonesia, Sejarah Pembentukan Undang-Undang Pokok Agraria, Isi dan Pelaksanaannya, Jakarta: Djambatan, 2003.

Direktorat Pemberdayaan Waqaf, Fiqih Waqaf, Jakarta :Departemen Agama RI, 2007.

Departemen Agama, Bunga Rampai Perwakafan, Jakarta: Ditjen Bimas Islam, Direktorat Pemberdayaan Wakaf, 2006.

Departemen Agama, Paradigma Baru Wakaf di Indonesia, Jakarta: Direktorat Pemberdayaan Wakaf Direktorat Jenderal Bimbingan Masyarakat Islam Departemen Agama RI , 2007.

Didin Hafidhuddin, Wakaf Uang Dalam Pandangan Syariat Islam, Jakarta: Kumpulan Hasil Seminar Perwakafan, Bimas dan Haji DEPAG RI, 2004.

Farida Prihartin dkk, Hukum Islam, Zakat dan waqaf, Teori dan Prakteknya di Indonesia, Jakarta: Papas Sinar Sinanti dan Fak. Hukum UI, 2005.

Huswatun Hasanah, Strategi Pengelolaan Wakaf Dalam Meningkatkan Kesejabteraan Umat, Jakarta: Kumpulan Hasil Seminar Perwakafan, Bimas dan Haji DEPAG RI, 2004.

Jaih Mubarok, Wakaf Produktif, Bandung: Simbiosa Rekatama Media, 2008.

Mukhlisin Muzarie, Hukum perwaqafan, Jakarta : Kementrian Agama RI, 2010.

Siah Khosyiah, Wakaf dan Hibah Perspektif Fiqh dan Perkembangannya Di Indonesia, Bandung: Pustaka Setia, 2010. 
Mundzir Qahar, Manajeman wakaf produktif, Jakarta: P'T Khalifa, 2005.

M.Cholil Nafis, Potensi Wakaf Produktif Untuke Kesejahteraan Umat, Pontianak, Fakultas Syariah dan Ekonomi Islam, 2014.

Muhammad Daud Ali, 2006, Sistim Ekonomi Islam Zakat dan Wakaf, Jakarta, UI Press, 2006.

Muhammad Abid Abdullah Al-Kabisi, Hukum Wakaf: Kajian Kontemporer Pertama dan Terlengkap tentang Fungsi dan Pengelolaan Wakaf Serta Penyelesaian atas Sengketa Wakaf Jakarta: IIMaN Press, 2003.

Mannan, Sertifikat Wakaf Tunai, Depok: Ciber, 2007.

Muhammad, Prinsip-Prinsip Ekonomi Islam, Yogyakarta: Graha Ilmu, 2007.

Muhammad, Ekonomi Islam, Malang: Empat Dua, 2009.

Muhammad Yusuf, Pemberdayaan Wakaf Produktif Untuk Pemberdayaan Ekonomi Umat, (Semarang: Badan Wakaf Nusantara, 2009 .

M. Syafii Antonio, Cash Waqf Dan Anggaran Pendidikan, Kumpulan Hasil Seminar
Perwakafan, Jakarta: Bimas dan Haji DEPAG RI, 2004.

Rachmadi Usman, Hukum Perwakafan di Indonesia. Jakarta:Sinar Grafika, 2009.

R. Abdul Djamali. Hukum Islam. Bandung: Mandar Jaya.

\section{Peraturan Perundang-undangan :}

Undang-Undang Dasar Negara Republik Indonesia Tahun 1945.

Ketetapan Majelis Permusyawaratan Rakyat Republik Indonesia Nomor IX/MPR/2001 tentang Pembaharuan Agraria dan Pengelolaan Sumber Daya Alam.

Kitab Undang-Undang Hukum Perdata

Undang-Undang nomor 5 Tahun 1960 Tentang Peraturan Dasar Pokok-Pokok Agraria

Undang-Undang Nomor 41 Tahun 2004 Tentang Wakaf

Peraturan Pemerintah Nomor 42 Tahun 2006 Tentang Pelaksanaan Undang-Undang Nomor 41 Tahun 2004 Tentang Wakaf 